\title{
Allometric biomass equations for Scots pine (Pinus sylvestris L.) seedlings during the first years of establishment in dense natural regeneration
}

\author{
Guy Geudens*, Jeroen StaELENS, Vincent KinT, Robbie GoRIS, Noël LuST \\ Laboratory of Forestry, Ghent University, Geraardsbergsesteenweg 267, 9090 Melle-Gontrode, Belgium
}

(Received 9 February 2004; accepted 13 September 2004)

\begin{abstract}
A dense natural regeneration of Scots pine (Pinus sylvestris L.) exhibits a considerable biomass build-up in the first four years, with amounts of $7.03 \mathrm{Mg} \mathrm{ha}^{-1}$ for aboveground biomass, and $0.88 \mathrm{Mg} \mathrm{ha}^{-1}$ for coarse root biomass $(>1 \mathrm{~mm})$. Power equations were developed, which relate collar diameter (ranging from 0.3 to $2.7 \mathrm{~cm}$ ) and height to total aboveground and coarse root biomass of two, three and four-yearold seedlings in a regeneration of 16 seedlings $\mathrm{m}^{-2}$ at one site in Belgium. During the first years of establishment, seedling allometry changes with age, whilst the density remains constant. Biomass equations developed for one of the three ages can produce biased predictions for the other ages. Even when an equation is based on data for all ages and information on height is included, age still has to be considered as a potential predictor variable. For pooled ages, linear regression after logarithmic transformation of the power equation, selected other predictors than weighted non-linear regression. The former approach indicated significant interactions between predictors, while the latter does not reveal interactions.
\end{abstract}

allometry / aboveground biomass / coarse root biomass / seedling / Pinus sylvestris L.

Résumé - Équations d'allométrie de biomasse pour semis de pin sylvestre (Pinus sylvestris L.) dans les premières années d'établissement d'une régénération naturelle dense. Une régénération naturelle dense de pin sylvestre (Pinus sylvestris L.) montre une accroissement considérable de biomasse dans les quatre premières années, avec des quantités de 7,03 $\mathrm{Mg}^{-1}$ pour la biomasse aérienne et $0,88 \mathrm{Mg} \mathrm{ha}^{-1}$ pour la biomasse des grosses racines $(>1 \mathrm{~mm})$. Des équations de type puissance mettant en relation le diamètre au niveau du collet racinaire (intervalle de 0,3 à $2,7 \mathrm{~cm}$ ) et la hauteur avec la biomasse aérienne et la biomasse des grosses racines de semis de pin sylvestre âgés de deux, trois et quatre ans ont été développées dans une régénération d'une densité de $16 \mathrm{semis}^{-2}$ sur un site en Belgique. Entre la deuxième et la quatrième année, à densité stationnaire, la relation d'allométrie des semis change avec l'âge. Les équations de biomasse développées pour les semis d'un même âge, peuvent produire des prédictions erronées pour les autres âges. Même en utilisant des donnés de tous les âges et la variable hauteur, l'âge doit être considéré comme une variable potentielle dans l'analyse de régression. En utilisant des donnés de tous les âges, l'analyse de régression linéaire a retenu différentes variables que l'analyse de régression non-linéaire pondérée. La première désignait des interactions significatives, tandis que la dernière ne considère pas les interactions.

allométrie / biomasse aérienne / biomasse racinaire forte / semis / Pinus sylvestris $\mathbf{L}$.

\section{INTRODUCTION}

Forest stand regeneration techniques based on spontaneous seedling establishment fit the needs of a low-energy and costefficient conversion of coniferous plantations into more natural forest types in Western and Central Europe [35]. This is particularly true for natural regeneration induced in gaps or under shelter, with an abundant seed source of the same species. Furthermore, if forest floor conditions are suitable then the seedling density is high [17]. In the establishment stage, densities are typically more than 1 seedling $\mathrm{m}^{-2}$ (up to 10 and more), compared to less than 1 seedling $\mathrm{m}^{-2}$ for plantations $[5,8,9$, $13,21,28,29]$.
Most empirical allometric biomass equations are confined to pole-stage and mature stands of planted forests. Extrapolating these equations to smaller diameters far outside of the data range used to develop them is questionable [7, 36]. Moreover, the high density of a young natural regeneration must be taken into account to avoid underestimation of the belowground biomass. Litton et al. [15] found that smaller mean tree size associated with increased stand density, appears to result in an increased relative allocation of biomass below ground for young trees of the same age. It is difficult to investigate whether allometric relationships change with increasing age at a constant (high) density, since in most tree stands density decreases rapidly with increasing age due to self-thinning or thinning operations.

\footnotetext{
* Corresponding author: Guy.Geudens@UGent.be
} 
Table I. Size characteristics of the sampled Scots pine seedlings.

\begin{tabular}{|c|c|c|c|c|c|}
\hline Variable & $\begin{array}{c}\text { Age } \\
\text { (years) }\end{array}$ & $N$ & $\begin{array}{l}\text { Mean } \\
(\mathrm{cm})\end{array}$ & $\begin{array}{l}\text { s.d. } \\
(\mathrm{cm})\end{array}$ & $\begin{array}{c}\text { Range } \\
(\mathrm{cm})\end{array}$ \\
\hline \multirow[t]{3}{*}{ Diameter } & 2 & 110 & 0.7 & 0.2 & $0.3-1.2$ \\
\hline & 3 & 134 & 1.0 & 0.3 & $0.3-2.0$ \\
\hline & 4 & 105 & 1.2 & 0.4 & $0.4-2.7$ \\
\hline \multirow[t]{3}{*}{ Height } & 2 & 110 & 20.0 & 6.6 & $6.0-36.0$ \\
\hline & 3 & 134 & 48.3 & 13.5 & $10.5-90.5$ \\
\hline & 4 & 105 & 84.3 & 20.7 & $27.5-131$ \\
\hline \multirow[t]{3}{*}{ Living crown length } & 2 & 110 & 17.6 & 6.5 & $3.8-33.0$ \\
\hline & 3 & 134 & 47.0 & 13.5 & $9.8-90.5$ \\
\hline & 4 & 105 & 57.3 & 15.8 & $21.5-99.0$ \\
\hline
\end{tabular}

In this paper our objectives are: (i) to develop allometric equations that enable the total aboveground biomass and coarse root biomass for two, three and four-year-old Scots pine (Pinus sylvestris L.) natural seedlings at high density to be predicted; (ii) to determine whether at a constant density, allometry changes with age between the second and the fourth year after emergence; and (iii) to compare resulting equations from nonlinear and linear regression analyses.

\section{MATERIALS AND METHODS}

\subsection{Study site}

Field measurements were conducted in a spontaneous regeneration of Scots pine in Herentals, Northern Belgium (51 ${ }^{\circ} 11^{\prime} \mathrm{N}$ and $4^{\circ} 48^{\prime} \mathrm{E}$, elevation $20 \mathrm{~m}$ ). The seedling cohort occupies a clearing in a 65 -yearold Scots pine plantation on a level site. The soil is a Plagganthrept Inceptisol [31] with a $65 \mathrm{~cm}$ thick homogeneous, anthropogenic, sandy top layer on sandy mother material and a clay substrate at $100 \mathrm{~cm}$ depth. The top $5 \mathrm{~cm}$ of mineral soil has a $\mathrm{pH}-\mathrm{H}_{2} \mathrm{O} 4.20 \pm 0.19$ and a $\mathrm{pH}-\mathrm{KCl} 3.06 \pm 0.16$. The climate is Atlantic maritime. The site is moderately dry, but between 1999 and 2002 the annual precipitation (869, 946,1032 and $993 \mathrm{~mm} \mathrm{year}^{-1}$ respectively) was well above the longterm average of $782 \mathrm{~mm}_{\text {year }}^{-1}$ [12]. In early 1999, the clearing was freed of debris and litter, but the mineral soil with pine stumps and dead roots was left undisturbed. In September 2000, an average of 16 seedlings $\mathrm{m}^{-2}$ had germinated during the 1999 growing season. New seedlings germinated in 2000 and 2001, but these had a limited growing space because of the high initial density in 1999. As a result of this, a second or third seedling cohort did not develop during the study period. The litter layer was less than $1 \mathrm{~cm}$ thick with little moss cover $(<5 \%)$ and very sparse other vegetation. No mortality was observed until after the fourth growing season.

\subsection{Data capture}

Three square sample plots of approximately $7 \mathrm{~m}^{2}$ were located in the centre of the clearing for homogeneous light conditions. After the growing season of 2000, the aboveground parts of 110 two-year-old seedlings were destructively sampled in the first plot. The collar diameter to the nearest $0.01 \mathrm{~cm}$ was measured over bark using an electronic calliper. The height between the root collar and the base of the terminal bud was measured to the nearest $5 \mathrm{~mm}$. Sampled seedlings were cut off at the root collar. Stem, branches, needles and buds were not separated. After the samples had been oven-dried for 2 days at $70{ }^{\circ} \mathrm{C}$, the dry mass was determined on an electronic balance to the nearest $0.01 \mathrm{~g}$. For 67 of these seedlings, all roots in the top $10 \mathrm{~cm}$ of the mineral soil with a diameter greater than $1 \mathrm{~mm}$ diameter were measured. For a study of root system geometry (not presented here), diameter measurements to the nearest $0.1 \mathrm{~mm}$ were made at intervals using an electronic calliper. Fresh root volume was calculated by approximating coarse root segments as cylinders with a diameter equal to the mean of both end diameters. A conversion coefficient from fresh coarse root volume to coarse root biomass was determined on a separate sample taken outside the plot, which consisted of 363 root segments that were pooled before weighing.

In 2001, similar procedures were used to measure aboveground biomass of 134 three-year-old seedlings in the second plot as well as the root systems of 71 of these seedlings. Finally, 105 four-year-old seedlings in the third plot were sampled in 2002. The coarse root system of 55 of these seedlings was collected, dried and weighed in the same way as the aboveground parts.

The seedling cohort is characterized in Table I.

Ground area based biomass for each of the three ages was obtained by dividing the measured aboveground biomass and the model-estimated coarse root biomass of all seedlings by the exact plot surface. Fine root biomass $(<1 \mathrm{~mm}$ diameter $)$ and biomass shed to the litter layer were not included.

\subsection{Regression analysis}

Stem sapwood cross-sectional area (CSA) at crown base is presumed to be an excellent predictor of crown biomass [18] due to the functional role of sapwood in conducting water and nutrients between fine roots and leaves. In very young seedlings, sapwood CSA encompasses almost the total stem CSA [2], and in pine seedlings the stem taper between the root collar and the crown base is limited. Collar diameter is proportional to the square root of the CSA and because it is measured at the intersection of both plant halves, it may serve as a predictor of both aboveground and belowground biomass quantities $[10,11,15,32]$. Other potential predictor variables include height $H$, and the derivate $D^{2} H[19,24,33]$. Living crown length is only marginally different from height for the seedlings at ages 2 and 3 years (Tab. I) [24].

The general allometric equation used is

$$
Y=\mathrm{a} X^{\mathrm{b}}+\varepsilon
$$


where $Y$ is oven-dry mass $(\mathrm{kg}), X$ is a tree dimension variable: collar diameter $(D$ in $\mathrm{cm})$, height $(H$ in $\mathrm{cm})$ or $D^{2} H\left(\mathrm{~cm}^{3}\right)$, a and b are parameters and $\varepsilon$ is a random normally distributed additive error term with constant variance [30,34]. Estimating parameters while satisfying the assumptions of regression analysis can be achieved by using: (i) weighted non-linear least squares estimation or (ii) ordinary least squares estimation after logarithmic transformation to a linear model [6].

Weighted non-linear least squares estimation ensures that the more variable larger seedlings contribute less to the parameter estimates than the smaller ones. The weights were derived from the function $X^{-\mathrm{w}}$, which is used to estimate the unknown variance $\sigma_{i}^{2}$ for each level i of $X$. We chose $w$ as the value that resulted in non-significant heteroscedasticity of the residuals, while minimizing the standard error of the estimate (SEE). We tested for significant heteroscedasticity with Levene's test statistic, comparing the variance of the residuals between four even-sized groups along the range of $X$. Initial parameter values for the non-linear regression (Gauss-Newton method) were taken from the fit of a logarithmic model (see below). Due to the non-linear nature of the power function and the use of weighted least squares estimation, the coefficient of determination $\left(R^{2}\right)$ has no clear-cut meaning and its use as a goodness-of-fit parameter is therefore questionable [20]. We therefore used SEE.

A second approach used was ordinary least squares estimation after logarithmic transformation of both sides of the power equation:

$$
\ln Y=\ln \mathrm{a}+\mathrm{b} \cdot \ln X+\varepsilon^{\prime} .
$$

This is not the exact logarithmic transformation of (1) due to the additive nature of the error term $[18,25,36]$ and therefore we do not fully support this approach. However, as it is widely used, we present the parameter estimates for comparison. Furthermore, it enables the interaction between multiple predictors to be analysed. Logarithmic transformation allows the use of $R^{2}$ and SEE as goodness-of-fit statistics, if $\ln a$ is different from zero [32]. Comparison of SEE between both approaches (logarithmic units versus arithmetic units) is not possible $[24,30]$. A logarithmic bias correction term, MSE/2, was added to the intercept before backtransformation, to ensure that the power equation estimates the mean of dry mass rather than the median for each diameter level [1].

The statistical analysis was carried out using the nls and $1 \mathrm{~m}$ functions in S-PLUS (version 6.0 Release 2, Insightful Corp.). Significance of the regression parameters was determined using $t$-tests. Residual diagnostics were examined in SPSS (version 11.0.1, SPSS Inc.)

\subsection{Dependency of age}

Bond-Lamberty et al. [3] and Reed et al. [27] added an indicator variable for age to a logarithmic equation in order to test if one biomass equation is appropriate for multi-aged data. Using pooled two, three and four-year-old seedling data, we added the variable $A$, i.e. age in years, to equations (1) and (2) to enable the parameter estimates of both approaches to be compared.

$$
\begin{gathered}
Y=\mathrm{a} X^{\mathrm{b}} A^{\mathrm{c}}+\varepsilon \\
\ln Y=\ln \mathrm{a}+\mathrm{b} \ln X+\mathrm{c} \ln A+\mathrm{d} \ln A \times \ln X+\varepsilon^{\prime} .
\end{gathered}
$$

Another way of testing the appropriateness of equations for different ages is to use the percentage of mean observed values (PMOV), which is also a goodness-of-fit statistic in regression analysis [24]. The biomass of the seedlings of age $A_{i}$ is estimated with the equation developed for age $A_{j}$. The mean of these estimations is then expressed as a percentage of the mean of the observed biomass values of the seedlings of age $A_{i}$ [33].
Table II. Biomass stock $\left(\mathrm{Mg} \mathrm{ha}^{-1}\right)$ in two, three and four-year-old dense Scots pine seedling cohorts (percentages between brackets). Coarse root biomass estimates based on single-age $D^{2} H$ equations in Table III.

\begin{tabular}{llll}
\hline Compartment & \multicolumn{3}{c}{ Age (years) } \\
\cline { 2 - 4 } & \multicolumn{1}{c}{2} & \multicolumn{1}{c}{3} \\
\hline Aboveground & $1.43(85)$ & $4.00(89)$ & $7.03(89)$ \\
Coarse root & $0.26(15)$ & $0.52(11)$ & $0.88(11)$ \\
Total living & 1.69 & 4.52 & 7.92 \\
\hline
\end{tabular}

\section{RESULTS}

\subsection{Living biomass stock}

Between the ages of 2 and 4 years, there is a strong increase in the total living biomass of Scots pine seedlings, i.e. from $1.7 \mathrm{Mg} \mathrm{ha}^{-1}$ to nearly $8 \mathrm{Mg} \mathrm{ha}^{-1}$ (Tabl. II). This increase is mainly due to the aboveground biomass, which accounts for $85-89 \%$ of the total living seedling biomass, excluding fine root mass.

\subsection{Regression equations}

For the three ages studied, the estimated parameters for the weighted non-linear regressions (Tab. III) were fairly similar to the parameters for the linear regressions after logarithmic transformation (Tab. IV) for the three ages, if the same predictors were selected. Nevertheless, both approaches lead to different model selections when height is added to a model that already contains collar diameter or, when ages are pooled, age is added to a model that already contains height or $D^{2} H$.

\subsection{Age dependence}

In pooled equations, the natural $\log$ arithm of age $(\ln A)$ is a significant predictor term for both aboveground and coarse root biomass, whether or not information on height is included by means of $\ln H$ or $\ln D^{2} H$ (Tab. IV). Interaction terms between $\ln A$ on the one hand and $\ln H$ or $\ln D^{2} H$ on the other are always significant in pooled equations. Using the weighted non-linear approach, age is not included when both diameter and height or $D^{2} H$ are already included in the model for aboveground biomass (Tab. III). For belowground biomass both approaches confirm the significance of the age predictor.

Using the $D^{2} H$ equations based on seedlings of a certain age to estimate the biomass of seedlings of other ages results in (i) estimated means that are between 38.3 and $129.7 \%$ of the observed mean biomass (Tab. V) for aboveground biomass, and (ii) estimated means between 27.6 and $338.6 \%$ of the observed mean (Tab. V) for coarse root biomass. Even the pooled equations based on seedlings of all ages do not accurately estimate the means of the observed biomasses in some of the ages considered. The aboveground biomass of two-yearold seedlings is underestimated by $26.3 \%$ and coarse root biomass of three-year-old seedlings is overestimated by $28.4 \%$. 
Table III. Weighted non-linear regression parameter estimates of allometric equation $Y=\mathrm{a} X^{\mathrm{b}}$. Parameters a, $\mathrm{b}$ and $\mathrm{c}$ (for the second predictor) are significant at the 0.01 level ( $t$-test).

\begin{tabular}{|c|c|c|c|c|c|c|c|c|c|c|c|c|c|}
\hline Age & $Y$ & $X$ & $\mathrm{a}$ & $\mathrm{b}$ & $\mathrm{c}$ & s.d. (a) & s.d. (b) & s.d. (c) & $N$ & SEE & $\mathrm{w}$ & Levene's $p$ & PMOV \\
\hline 2 & $M_{a}$ & $D$ & 0.0187 & 2.039 & & 0.0006 & 0.081 & & 110 & 0.00260 & 2.1 & 0.05 & 100.0 \\
\hline 2 & $M_{a}$ & $D^{2} H$ & 0.00190 & 0.680 & & 0.00011 & 0.029 & & 110 & 0.00310 & 1.8 & 0.07 & 99.6 \\
\hline 3 & $M_{a}$ & $D$ & 0.0189 & 2.287 & & 0.0003 & 0.051 & & 134 & 0.00473 & 4.0 & 0.22 & 100.8 \\
\hline 3 & $M_{a}$ & $D, H$ & 0.00305 & 1.916 & 0.474 & 0.00099 & 0.081 & 0.084 & 134 & 0.00414 & 4.1 & 0.29 & 102.0 \\
\hline 3 & $M_{a}$ & $D^{2} H$ & 0.000873 & 0.801 & & 0.000070 & 0.019 & & 134 & 0.00426 & 1.2 & 0.08 & 102.2 \\
\hline 4 & $M_{a}$ & $D$ & 0.0233 & 2.556 & & 0.0007 & 0.065 & & 105 & 0.0112 & 4.0 & 0.05 & 100.7 \\
\hline 4 & $M_{a}$ & $D, H$ & 0.000127 & 1.833 & 1.206 & 0.000087 & 0.112 & 0.158 & 105 & 0.00919 & 5.6 & 0.07 & 103.5 \\
\hline 4 & $M_{a}$ & $D^{2} H$ & 0.000332 & 0.983 & & 0.000033 & 0.021 & & 105 & 0.00923 & 1.9 & 0.03 & 100.0 \\
\hline Pool & $M_{a}$ & $D, A$ & 0.0163 & 2.343 & 0.247 & 0.0012 & 0.041 & 0.063 & 349 & 0.00822 & 4.1 & 0.06 & 97.6 \\
\hline Pool & $M_{a}$ & $D, H$ & 0.00788 & 2.139 & 0.257 & 0.00114 & 0.056 & 0.037 & 349 & 0.00762 & 3.8 & 0.05 & 99.3 \\
\hline Pool & $M_{a}$ & $D^{2} H$ & 0.00121 & 0.742 & & 0.00007 & 0.012 & & 349 & 0.00807 & 0.9 & 0.05 & 99.7 \\
\hline 2 & $M_{r}$ & $D$ & 0.00414 & 2.828 & & 0.00024 & 0.140 & & 67 & 0.000599 & 3.5 & 0.06 & 99.1 \\
\hline 2 & $M_{r}$ & $D^{2} H$ & 0.000184 & 0.929 & & 0.000022 & 0.064 & & 67 & 0.000734 & 2.2 & 0.09 & 97.9 \\
\hline 3 & $M_{r}$ & $D$ & 0.00222 & 2.812 & & 0.00008 & 0.137 & & 71 & 0.000828 & 3.6 & 0.83 & 99.0 \\
\hline 3 & $M_{r}$ & $D^{2} H$ & 0.0000601 & 0.934 & & 0.0000119 & 0.053 & & 71 & 0.000861 & 1.8 & 0.09 & 100.0 \\
\hline 4 & $M_{r}$ & $D$ & 0.00283 & 2.549 & & 0.00009 & 0.103 & & 55 & 0.00142 & 5.9 & 0.06 & 100.4 \\
\hline 4 & $M_{r}$ & $D^{2} H$ & 0.0000482 & 0.951 & & 0.0000090 & 0.041 & & 55 & 0.00127 & 2.1 & 0.07 & 101.6 \\
\hline Pool & $M_{r}$ & $D, A$ & 0.00513 & 2.656 & -0.547 & 0.00064 & 0.081 & 0.115 & 193 & 0.00106 & 3.4 & 0.06 & 99.1 \\
\hline Pool & $M_{r}$ & $D^{2} H, A$ & 0.000615 & 0.929 & -1.879 & 0.000066 & 0.035 & 0.173 & 193 & 0.00119 & 0.9 & 0.11 & 99.4 \\
\hline
\end{tabular}

Pool: all ages, $M_{a}$ : aboveground biomass and $M_{r}$ : coarse root biomass in $\mathrm{kg}, D$ : collar diameter in $\mathrm{cm}, H$ : height in $\mathrm{cm}, D^{2} H$ in $\mathrm{cm}^{3}, A$ : age in years, s.d. ( ): standard deviation of the parameter estimates, $N$ : sample size, SEE: standard error of the estimate, - w: power of the weighting function (see text), Levene's $p$ is the significance of the Levene's test statistic for equality of variances, PMOV: percentage mean observed value.

Table IV. Parameter estimates of allometric equation $Y=\mathrm{a} X^{\mathrm{b}}$ using linear regression after logarithmic transformation. The parameters a, $\mathrm{b}$ and $\mathrm{c}, \mathrm{d}$, e (for multiple predictors) are significant at the 0.01 level ( $t$-test).

\begin{tabular}{|c|c|c|c|c|c|c|c|c|c|c|c|c|c|c|c|c|c|}
\hline Age & $Y$ & $X$ & Interaction & $\mathrm{a}$ & $\mathrm{b}$ & $\mathrm{c}$ & $\mathrm{d}$ & $\mathrm{e}$ & s.d. (a) & s.d. (b) & s.d. (c) & s.d. (d) s.d. (e) & $N$ & $R^{2}$ & SEE & MSE/2 & MOV \\
\hline 2 & $M_{a}$ & $D$ & & 0.0189 & 2.068 & & & & 0.0008 & 0.077 & & & 110 & 0.869 & 0.247 & 0.030 & 100.3 \\
\hline 2 & $M_{a}$ & $D^{2} H$ & & 0.00191 & 0.678 & & & & 0.00012 & 0.030 & & & 110 & 0.826 & 0.284 & 0.040 & 99.1 \\
\hline 3 & $M_{a}$ & $D$ & & 0.0189 & 2.344 & & & & 0.0003 & 0.050 & & & 134 & 0.943 & 0.191 & 0.018 & 101.8 \\
\hline 3 & $M_{a}$ & $D, H$ & & 0.00305 & 1.946 & 0.474 & & & 0.00100 & 0.085 & 0.085 & & 134 & 0.954 & 0.172 & 0.015 & 102.6 \\
\hline 3 & $M_{a}$ & $D^{2} H$ & & 0.000831 & 0.813 & & & & 0.000053 & 0.017 & & & 134 & 0.948 & 0.182 & 0.016 & 100.4 \\
\hline 4 & $M_{a}$ & $D$ & & 0.0230 & 2.629 & & & & 0.0006 & 0.069 & & & 105 & 0.934 & 0.245 & 0.030 & 102.6 \\
\hline 4 & $M_{a}$ & $H$ & & $1.33 \mathrm{E}-08$ & 3.362 & & & & 7.6E-09 & 0.131 & & & 105 & 0.865 & 0.351 & 0.060 & 96.6 \\
\hline 4 & $M_{a}$ & $D^{2} H$ & & 0.000324 & 0.988 & & & & 0.000032 & 0.021 & & & 105 & 0.957 & 0.199 & 0.020 & 99.8 \\
\hline Pool & $M_{a}$ & $D, A$ & $\ln D \cdot \ln A$ & 0.0138 & 1.228 & 0.336 & 1.035 & & 0.0009 & 0.136 & 0.060 & 0.123 & 349 & 0.949 & 0.230 & 0.026 & 99.4 \\
\hline Pool & $M_{a}$ & $D, H, A$ & $\ln H \cdot \ln A$ & 0.140 & 1.999 & -0.426 & -3.615 & 0.850 & 0.041 & 0.057 & 0.091 & 0.3120 .078 & 349 & 0.957 & 0.210 & 0.022 & 99.4 \\
\hline Pool & $M_{a}$ & $D^{2} H, A$ & $\ln D^{2} H \cdot \ln A$ & 0.00934 & 0.400 & -2.304 & 0.401 & & 0.00113 & 0.040 & 0.137 & 0.036 & 349 & 0.951 & 0.225 & 0.025 & 99.5 \\
\hline 2 & $M_{r}$ & $D$ & & 0.00449 & 3.012 & & & & 0.00037 & 0.157 & & & 67 & 0.850 & 0.377 & 0.070 & 104.3 \\
\hline 2 & $M_{r}$ & $D^{2} H$ & & 0.000179 & 0.947 & & & & 0.000022 & 0.065 & & & 67 & 0.769 & 0.468 & 0.010 & 102.5 \\
\hline 3 & $M_{r}$ & $D$ & & 0.00224 & 2.856 & & & & 0.00009 & 0.129 & & & 71 & 0.877 & 0.324 & 0.015 & 99.5 \\
\hline 3 & $M_{r}$ & $D^{2} H$ & & $5.53 \mathrm{E}-05$ & 0.957 & & & & $9.4 \mathrm{E}-06$ & 0.049 & & & 71 & 0.850 & 0.359 & 0.064 & 101.0 \\
\hline 4 & $M_{r}$ & $D$ & & 0.00283 & 2.568 & & & & 0.00009 & 0.090 & & & 55 & 0.939 & 0.217 & 0.023 & 101.2 \\
\hline 4 & $M_{r}$ & $D^{2} H$ & & $4.80 \mathrm{E}-05$ & 0.951 & & & & 8.1E-06 & 0.037 & & & 55 & 0.927 & 0.236 & 0.027 & 101.6 \\
\hline Pool & $M_{r}$ & $D, A$ & & 0.00550 & 2.790 & -0.596 & & & 0.00072 & 0.087 & 0.123 & & 193 & 0.881 & 0.369 & 0.067 & 103.8 \\
\hline Pool & $M_{r}$ & $D, H, A$ & $\ln H \cdot \ln A$ & 0.0827 & 2.599 & -0.707 & -4.299 & 0.928 & 0.0512 & 0.132 & 0.188 & $0.719 \quad 0.175$ & 193 & 0.896 & 0.346 & 0.059 & 100.1 \\
\hline Pool & $M_{r}$ & $D^{2} H, A$ & $\ln D^{2} H \cdot \ln A$ & 0.00174 & 0.559 & -3.054 & 0.375 & & 0.00047 & 0.095 & 0.327 & 0.088 & 193 & 0.863 & 0.396 & 0.077 & 100.0 \\
\hline
\end{tabular}

Symbols as in Table II; $R^{2}$ : adjusted coefficient of determination; MSE/2: correction term added to lna before backtransformation to a; numbers in italics are in logarithmic units and the rest are in arithmetic units. 

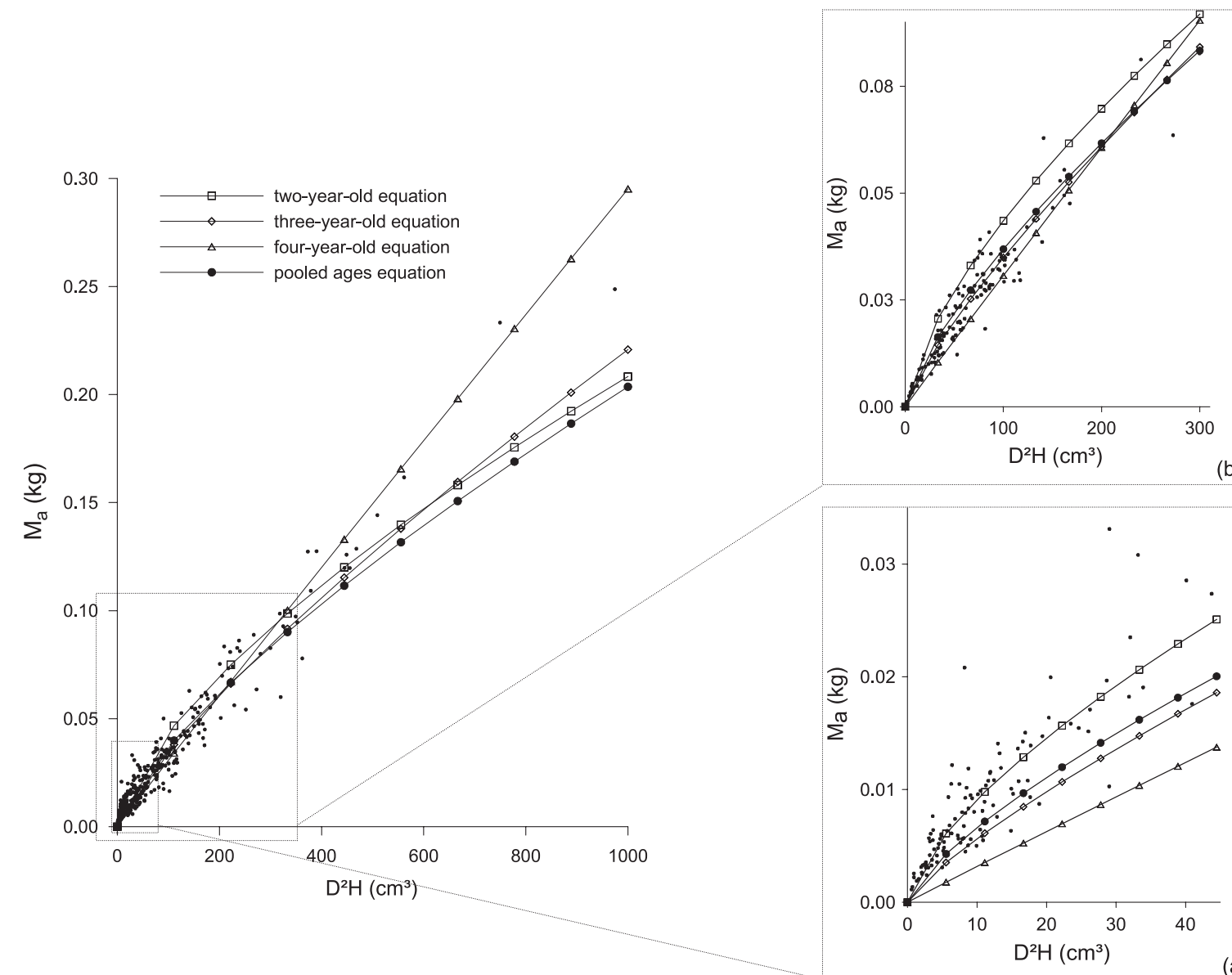

(b)

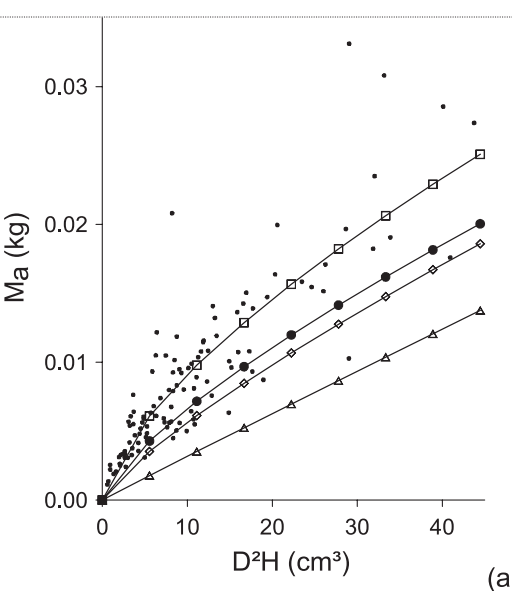

Figure 1. Aboveground Biomass $\left(M_{a}\right)$ as a function of $D^{2} H$ : equations of different ages and of pooled ages from Table III. The insets enlarge the figure for the two-year-old seedlings (a) and the three-year-old seedlings (b).

Table V. Percentage Mean Observed Value (\%): $D^{2} H$ equations (Tab. III) based on the respective ages applied to seedlings of other ages.

\begin{tabular}{lcrrrr}
\hline \multirow{2}{*}{$Y$} & Age & \multicolumn{4}{c}{ Age of the observations } \\
\cline { 3 - 6 } & & 2 & 3 & 4 & Pooled \\
\hline$M_{a}$ & 2 & & 129.7 & 114.0 & 117.6 \\
$M_{a}$ & 3 & 63.7 & & 101.2 & 97.5 \\
$M_{a}$ & 4 & 38.3 & 84.0 & & 88.1 \\
$M_{a}$ & Pooled & 73.7 & 106.8 & 99.8 & \\
& & & & & \\
$M_{r}$ & 2 & & 293.8 & 338.6 & 282.8 \\
$M_{r}$ & 3 & 33.1 & & 115.9 & 96.6 \\
$M_{r}$ & 4 & 27.6 & 85.9 & & 87.4 \\
$M_{r}$ & Pooled & 91.7 & 128.4 & 86.2 & \\
\hline
\end{tabular}

As can be seen in Figure 1, the relation between aboveground biomass and $D^{2} H$ clearly differs between the three ages within the diameter and height range measured.

\section{DISCUSSION}

\subsection{Single-age equations}

The equations in Tables III and IV are applicable to Scots pine seedlings in a dense even-aged regeneration at the site in the present study from the end of the second growing season after seedling emergence until the end of the fourth season, when mortality appears due to intense competition. The relationships found here can be used for inferences nearby the origin, i.e. for small diameters of the allometric biomass curves for different ages [3]. Recently much emphasis has been placed on the small diameter classes when general equations for a wide range of ages and sizes are sought [37]. Crown sampling strategies did not influence the resulting allometric equations, because entire crowns and coarse root systems were sampled [18]. Fine roots $(<1 \mathrm{~mm})$ were not considered. A better means of obtaining fine root biomass estimates at the stand level is to sample with a soil corer on a per soil surface or volume basis $[22,23]$. Furthermore, seasonal fluctuations in root biomass of Scots pine are concentrated in the diameter class smaller than $1 \mathrm{~mm}[26]$. 
Collar diameter proved to be the main predictor for estimating aboveground and coarse root biomass of seedlings of the same age. Although Litton et al. [15] proved that models based on outside bark basal diameter show a slight bias towards the overprediction of belowground biomass for diameters less than $3 \mathrm{~cm}$, we did not observe such a systematic bias in the residuals of the regressions (PMOV in Tabs. III and IV).

If the same predictors are selected, parameter estimates and their standard deviations from both non-linear and log-linear approaches are quite similar. According to Längström et al. [16], even backtransformation with correction can produce bias if the untransformed variable is not log-normally distributed. For the single-age equations, we consider the parameter values in Table III to be the best fits. The aboveground biomass of three and four-year-old seedlings is best predicted by diameter and height or $D^{2} H$, while for two-year-old seedlings diameter alone gives a better fit. For two and three-year-old seedlings coarse root biomass is best predicted by diameter, while for four-yearold seedlings this is best predicted by $D^{2} H$.

\subsection{Multiple ages}

Based on the equation parameters no conclusion can be drawn about the differences between ages when the same predictors are selected. Reed et al. [27] used standard deviations of the parameter estimates to test for significant differences between allometric equations. However, parameters $a$ and $b$ in equation (1) are well correlated [37] and therefore a separate comparison of these values is questionable.

The weighted non-linear regression approach (Tab. III), demonstrates that a multi-aged equation including $D^{2} H$ or diameter and height, fits the aboveground biomass data of two, three and four-year-old seedlings. For coarse root biomass an age variable still has to be included. Using the linear regression approach after logarithmic transformation (Tab. IV), age and one interaction with another predictor are always significant for both aboveground and coarse root biomass. Accordingly, both methods lead to a different conclusion concerning the need to include age in multi-aged allometric aboveground biomass equations for the pine seedlings in this study. The percentage mean observed values confirm the above finding that allometric relationships for consecutive years are not equivalent. For example, equations for two-year-old seedlings underestimate mean aboveground biomass in three-year-old seedlings by more than the $20 \%$, which Wang et al. [33] proposed as the limit for comparability.

Allometric relationships for seedlings seem to be species specific [32]. For Scots pine they do not seem to be specific for geographical seed origin if one age at one site is considered [22]. With respect to the dependence of size and age, Braekke [4] found that the slope of a linear relation which related squared diameter at breast height to the total aboveground biomass of young Scots pine trees growing in a dense natural regeneration, was different for trees above and below the limit of $7 \mathrm{~cm}$ stem diameter. Consequently he used two separate equations for smaller and larger trees. In a 46-year-old Scots pine stand, Lim and Cousens [14] found a systematic underestimation of biomass when allometric equations developed from data in a certain year, were applied to the trees in a successive year. This underestimation was 0.5 to 1 percent per year. There- fore, the influence of age seems to be more important in the youngest stands. However, Reed et al. [27] concluded that relationships between collar diameter and aboveground and belowground biomass were consistent from the time of establishment through the onset of inter-tree competition. Indicator variables for age and the interactions with predictor variables $D$ and $H$ were not significant in a logarithmically transformed regression model, even though the young Pinus resinosa Ait. in their data set ranged from 1 to 8 years of age after planting and from 0.3 to $10.1 \mathrm{~cm}$ in collar diameter. The pines in the study of Reed et al. [27] were planted as three-year-old seedlings at a density of $1 \mathrm{~m}^{-2}$, and the first aboveground physical interaction was observed 6 years later. For the Scots pine seedlings in our study, root system overlap was considerable at the age of 2 years, and in the third growing season crown contact was common. Mortality of the lowest branch whirls was common at the end of the fourth growing season (Tab. II) when first seedling mortality in the regeneration cohort also occurred. At the high densities common in natural regenerations of Scots pine, the pre-competitive state seems to be restricted to the first 1 or 2 years of establishment, which may account for the change in allometric relationships between the ages of 2 and 4 years.

\section{CONCLUSIONS}

A dense natural regeneration of Scots pine exhibits a considerable biomass build-up during the first years of establishment. A general allometric equation for aboveground or coarse root biomass intended to be valid for these ages, with collar diameter, height or $D^{2} H$ as predictors, should be based on observations of several ages and age should be tested as a predictor variable. Although weighted non-linear regression analysis is a statistically more reliable approach than linear regression after logarithmic transformation of an allometric power equation, the latter enables investigation of interactions between predictor variables.

Acknowledgements: We thank Renaat Verhoeven for putting the site at our disposal and Elke Campforts and Caroline Ryssaert for their assistance with the fieldwork. Comments by two anonymous reviewers and David Hibbs helped us a lot to improve an early version. This study was financed by Ph.D. grants from the B.O.F. research fund of the Ghent University and the Fund for Scientific Research, Flanders, Belgium (F.W.O.-Vlaanderen).

\section{REFERENCES}

[1] Baskerville G.L., Use of logarithmic regression in the estimation of plant biomass, Can. J. For. Res. 2 (1972) 49-53.

[2] Björklund L., Identifying heartwood-rich stands or stems of Pinus sylvestris by using inventory data, Silva Fenn. 33 (1999) 119-129.

[3] Bond-Lamberty B., Wang C., Gower S.T., Aboveground and belowground biomass and sapwood area allometric equations for six Boreal tree species of northern Manitoba, Can. J. For. Res. 32 (2002) 1441-1450.

[4] Braekke F.H., Distribution and yield of biomass from young Pinus sylvestris and Picea abies stands on drained and fertilized peatland, Scand. J. For. Res. 1 (1986) 49-66.

[5] Béland M., Agestam E., Ekö P.M., Gemmel P., Nilsson U., Scarification and seedfall affects natural regeneration of Scots pine under 
two shelterwood densities and a clear-cut in Southern Sweden, Scand. J. For. Res. 15 (2000) 247-255.

[6] Carroll R.J., Ruppert D., Transformation and weighting in regression, Chapman and Hall, New York, 1988.

[7] Claesson S., Sahlén K., Lundmark T., Functions for biomass estimation of young Pinus sylvestris, Picea abies and Betula spp. from stands in Northern Sweden with high stand densities, Scand. J. For. Res. 16 (2001) 138-146.

[8] Dong P.H., Diep D.Q., Schüler G., Kiefern-Naturverjüngung in Pfälzerwald, Forst u. Holz 58 (2003) 83-86 (in German).

[9] Gothe H., Pflanzenzahlen und Oberhöhen in einigen charakterischen Kiefern-Naturverjüngungen im Gräflichen Forstamt Schlitz, Allg. Forst- u. J.-Ztg. 127 (1956) 228-232 (in German).

[10] Hoffmann C.W., Usoltsev V.A., Modelling root biomass distribution in Pinus sylvestris forests of the Turgai Depression of Kazachstan, For. Ecol. Manage. 149 (2001) 103-114.

[11] Jalkanen A., Covariances between morphological characteristics in bareroot Pinus sylvestris nursery stock, Scand. J. For. Res. 8 (1993) 540-549.

[12] KMI, Precipitation data of station Viersel, Royal Meteorological Institute of Belgium, Ukkel, 2003.

[13] Kupka I., Natural regeneration at different microclimatic sites in Zatec region, J. For. Sci. (Lesnictví) 48 (2002) 441-450.

[14] Lim M.T., Cousens J.E., The internal transfer of nutrients in a Scots pine stand. I. Biomass components, current growth and their nutrient content, Forestry 59 (1986) $1-16$.

[15] Litton C.M., Ryan M.G., Tinker D.B., Knight D.H., Belowground and aboveground biomass in young postfire lodgepole pine forests of contrasting tree density, Can. J. For. Res. 33 (2003) 351-363.

[16] Längström B., Piene H., Fleming R., Hellqvist C., Shoot and needle losses in Scots pine: experimental design and techniques for estimating needle biomass of undamaged and damaged branches, in: McManus M.L., Liebhold A.M. (Eds.), Proceedings: Population Dynamics, Impacts, and Integrated Management of Forest Defoliating Insects, General Technical Report NE-247, USDA Forest Service, 1998, pp. 230-246.

[17] Malcolm D.C., Mason W.L., Clarke G.C., The transformation of conifer forests in Britain - regeneration, gap size and silvicultural systems, For. Ecol. Manage. 151 (2001) 7-23.

[18] Monserud R.A., Marshall J.D., Allometric crown relations in three northern Idaho conifer species, Can. J. For. Res. 29 (1999) 521-535.

[19] Návar J., Méndez E., Dale V., Estimating stand biomass in the Tamaulipan thornscrub of northeastern Mexico, Ann. For. Sci. 59 (2002) 813-821.

[20] Neter J., Kutner M.H., Nachtsheim C.J., Wasserman W., Applied Linear Statistical Models, WCB McGraw-Hill, Boston, 1996.

[21] Nilsson U., Gemmel P., Johansson U., Karlsson M., Welander T., Natural regeneration of Norway spruce, Scots pine and birch under
Norway spruce shelterwoods of varying densities on a mesic-dry site in southern Sweden, For. Ecol. Manage. 161 (2002) 133-145.

[22] Oleksyn J.J., Reich P.B., Chalupka W., Tjoelker M.G., Differential above- and below-ground biomass accumulation of European Pinus sylvestris populations in a twelve-year-old provenance experiment, Scand. J. For. Res. 14 (1999) 7-17.

[23] Ovington J.D., Madgwick H.A.I., Distribution of organic matter and plant nutrients in a plantation of Scots pine, For. Sci. 5 (1959) 344-355.

[24] Parresol B.R., Assessing tree and stand biomass: a review with examples and critical comparisons, For. Sci. 45 (1999) 573-593.

[25] Payandeh B., Choosing regression models for biomass prediction equations, For. Chron. 57 (1981) 229-232.

[26] Persson H., Root dynamics in a young Scots pine stand in central Sweden, Oikos 30 (1978) 508-519.

[27] Reed D.D., Mroz G.D., Liechty H.O., Jones E.A., Cattelino P.J., Balster N.J., Zhang Y., Above- and below-ground biomass of precompetitive red pine in northern Michigan, Can. J. For. Res. 25 (1995) 1064-1069.

[28] Richardson A.D., Bealle Statland C., Gregoire T.G., Root biomass distribution under three cover types in a patchy Pseudotsuga menziesii forest in western Canada, Ann. For. Sci. 60 (2003) 469-474.

[29] Seitz R., Untersuchungen zur natürlichen Verjüngung der Kiefer (Pinus sylvestris L.) in Bayern (Mittelfranken, Oberfranken und Oberpfalz), Dissertation, Forstwissenschaftliche Fakultät der Universität München, 1980 (in German).

[30] Ter-Mikaelian M.T., Korzukhin M., Biomass estimations for 65 North American tree species, For. Ecol. Manage. 97 (1997) 1-24.

[31] USDA, Keys to Soil Taxonomy, United States Department of Agriculture, Natural Resources Conservation Service, Soil Survey Staff, 1998.

[32] Wagner R.G., Ter-Mikaelian M.T., Comparison of biomass component equations for four species of northern coniferous tree seedlings, Ann. For. Sci. 56 (1999) 193-199.

[33] Wang J.R., Zhong A.L., Kimmins J.P., Biomass estimation errors associated with the use of published regression equations of Paper birch and Trembling aspen, North. J. Appl. For. 19 (2002) 128-136.

[34] West G.B., Brown J.H., Enquist B.J., A general model for the structure and allometry of plant vascular systems, Nature 400 (1999) 664-667.

[35] Zerbe S., Restoration of natural broad-leaved woodland in Central Europe on sites with coniferous forest plantations, For. Ecol. Manage. 167 (2002) 27-42.

[36] Zianis D., Mencuccini M., Aboveground biomass relationships for beech (Fagus moesiaca Cz.) trees in Vermio Mountain, Northern Greece, and generalised equations for Fagus sp., Ann. For. Sci. 60 (2003) 439-448.

[37] Zianis D., Mencuccini M., On simplifying allometric analyses of forest biomass, For. Ecol. Manage. 187 (2004) 311-332. 